\title{
Tell Me, Who Is Your Friend: Concept of FRIEND in the Modern Russian Media Discourse (on the Material of the Russian National Corpus 2014)
}

\author{
Makarova Viktorija Vladimirovna ${ }^{1}$ \\ Associate Professor of Vilnius University, \\ Vilnius, Lithuania. \\ (date of receiving: April, 2018; date of acceptance: August, 2018)
}

\begin{abstract}
The article presents the results of a study about FRIEND as a Russian concept one of the most striking Culture Specific (in terms of A. Wierzbicka) Russian concepts that attracted and still attract the attention of many linguists. The experience of our predecessors has shown that the Russian concept of FRIEND as a result of various social, historical processes undergoes certain changes in structure and substantive content. The aim of our study was to determine the content and structure of the Russian concept of FRIEND in contemporary Russian media discourse. The study used data from the National corpus of the Russian language as the source materials: a search was carried out on newspaper co-variation; the search criteria were the parameters of "adjective + FRIEND noun" at a distance of 1 word from each other. After exclusion of irrelevant examples (e.g., in the case of homonyms of adverbs and short forms of adjectives) a sample of 150 examples was obtained for the analysis (for example, a German friend, good friend, new friends, best friend).
\end{abstract}

Keywords: Concept, World View, Friend, Friendship, Media Discourse, Russian National Corpus.

1.E-mail: makarovavv@gmail.com 


\title{
Скажи мне, кто твой друг: концепт друг в современном русском медиадискурсе (на материале НКРЯ 2014 г.)
}

\author{
Макарова Виктория Влладимировна ${ }^{1}$ \\ Доцент, Вильнюсский университет, \\ Вильнюс, Литва.
}

(дата получения: апрель 2018 г.; дата принятия: август 2018 г.)

\begin{abstract}
Аннотация
В статье представлены результаты исследования русского концепта друг одного из наиболее ярких культурспецифичных (в терминах А. Вежбицкой) русских концептов, привлекавших и по-прежнему привлекающих внимание многих лингвистов. Опыт наших предшественников показал, что русский концепт друг в результате различных социальных, исторических процессов претерпевает определенные изменения в структуре и содержательном наполнении. Целью нашего исследования было установить, каково содержательное наполнение и структура русского концепта друг в современном русском медиадискурсе. В качестве источника материалов для исследования использовались данные Национального корпуса русского языка: поиск осуществлялся по газетному подкорпусу, заданньми критериями поиска служили параметры «прилагательное + существительное друг» на расстоянии 1 слова друг от друга. После исключения нерелевантньх примеров (например, в случае омонимии наречия и краткого прилагательного) для анализа была получена выборка из 150 примеров (например, немецкому другу, хорошего друга, к новым друзьям, лучшим другом).
\end{abstract}

Ключевые слова: Концепт, Картина Мира, Друг, Дружба, Медиадискурс, НКРЯ.

1. E-mail: makarovavv@gmail.com 


\section{Введение}

В 1997 г. Анна Вежбиццая опубликовала работу о моделях дружбы в разных культурах на английском языке, перевод этого труда на русском языке появился в 2001 г. (Вежбицкая 2001), и с тех пор лингвистами было предпринято исследование интересующей нас ментальной единицы - русского концепта ДРУГ - в самых разных аспектах: например, уточнение семантики слов друг, подруга, приятель, товарищ - в сопоставлении с выводами и Анны Вежбицкой, и других ученых (Шмелев 2002), сопоставление русской и английской картин мира на материале пословиц со словами друг и friend (напр., Пахомова 2015), анализ содержательного наполнения и структуры концепта ДРУЖБА посредством анализа русских паремиологических единиц о дружбе (Шутковский 2010, Чугаева 2016) и на более обширном материале (Арапова 2005), выявление социальных аспектов формирования русского концепта ДРУГ на материале текстов XII-XIX вв. (Попович 2016), лингвокультурологическое сопоставление вербальных реализаций русского концепта ДРУГ и английского концепта FRIEND (Хизова 2005), описание градиент-концепта ДРУЖБА-МИР-ВРАЖДА в русской и английской лингвокультурах (Лунцова 2008). Стали также появляться работы, в которых предпринимается попытка выявить основные особенности русского концепта ДРУЖБА на основании обобщения результатов анализа работ, посвященных исследованию этого концепта (Коняева 2014).

Цель настоящей работы заключалась в том, чтобы представить результаты анализа русского концепта ДРУГ, выполненного на материале медиадискурса (избранном для анализа потому, что именно медиадискурс считается одним из наиболее чувствительно реагирующих на различные социальные изменения по сравнению с другими дискурсами), причем исследована была одна актантная схема, а именно: словосочетания, в которых прилагательное согласовано с существительным друг. Важно, что полученные нами данные являются 
результатом анализа лишь одного фрагмента медиадискурса, и они не могут служить окончательными выводами о сущности концепта ДРУГ в современном русском медиадискурсе, но мы надеемся, что результаты нашего пилотного исследования все же представляют интерес, а в перспективе мы планируем продолжить наше исследование в следующем направлении: вопервых, исследовать микроконтексты, в которых лексема «друг» занимает различные позиции в актантных схемах, во-вторых, провести аналогичное исследование на материале литовского медиадискурса, в-третьих, описать содержательное наполнение и структуру концепта ДРУГ в современных русском и литовском медиадискурсах.

Для составления нашей выборки мы использовали данные Национального корпуса русского языка: поиск осуществлялся по газетному подкорпусу, заданными критериями поиска служили параметры «прилагательное + существительное ДРУГ», расположенные на расстоянии 1 слова друг от друга. После исключения нерелевантных примеров (например, в случае омонимии наречия и краткого прилагательного) мы получили сплошную выборку из 150 единиц анализа. Дата публикации всех источников полученных примеров относится к 2014 г.

\section{Основная часть}

\section{О частотности. Где верные друзья?}

Анализ нашей выборки показал, что наиболее частотными оказались следующие прилагательные, согласующиеся со словоформами слова друг: близкий (24 из 150 единиц анализа), лучиий (18 единиц анализа), старый (10 единиц анализа), больиой (8 единиц анализа).

Для осознания полученной нами информации о частотности повторяющихся слов, - прилагательных, использованных для характеристики ДРУГА, - мы обратились к данным «Ассоциативного словаря» (Черкасова 
2008). В данном словаре собраны результаты (но не все, а только по повторяющимся в 2 или 3 опросах словам-стимулам) трех массовых ассоциативных опросов, проведенных и/или опубликованных в 1977-1999 г.Г. в «Словаре ассоциативных норм русского языка» под ред. А.А. Леонтьева, «Русском ассоциативном словаре» и «Славянском ассоциативном словаре».

Какие прилагательные - в качестве стимулов на реакцию «друг» - являлись наиболее частотными в 1977-1999 г.г.? Во-первых, это, как показано в (Черкасова 2008), прилагательное верный, на втором месте по частотности располагаются хороиий и лучший или близкий (данные трех ассоциативных опросов немного варьируются).

Мы намеренно не сравниваем полученные нами данные и данные «Ассоциативного словаря» (Черкасова 2008) в числах, потому что наши данные о частотности прилагательных, согласованных с лексемой друг в нашей выборке, не были получены путем ассоциативного эксперимента. Однако нельзя не отметить следующий факт: стимул друг вызывал реакцию верный в ассоциативных экспериментах 1977-1999 г.г. (13,88 \% реакций на стимул «друг» в «Словаре ассоциативных норм русского языка», 12,87 \% - в «Русском ассоциативном словаре» и 10,46 \% - в «Славянском ассоциативном словаре»). Субъектам же анализированных нами медиатекстов не пришла в голову мысль употребить слово верный для характеристики крепких дружеских отношений. Почему? Может быть, дело в том, что в целом популярность ценности «верность» постепенно снижается в русской культуре? Но, как и чем измерить такую зыбкую величину, как верность? Косвенным свидетельством того, что верность ('надежность', 'раз и навсегда') не столь актуальна для современного россиянина, могут служить статистические данные о количестве разводов в России: их число (по сравнению с количеством браков) в последние годы растет (Демографический ежегодник России 2017. 50). Но это данные о супружеских отношениях. Что же касается 
понятия «верный друг», то на данный момент ограничимся констатацией факта о том, что ни одного упоминания о верном друге в 150 современных микроконтекстах из медиадискурса, полученных методом сплошной выборки, нам не встретилось.

\section{Об оценочности. 89 «+» vs. 3 «»}

Если сравнить количество примеров, в которых словоформы лексемы «друг» сочетаются со словами с оценочной окраской (в ряде случаев положительная коннотация возникает именно в сочетании со словом друг; например, большой друг), то мы увидим следующую картину: 89 единиц с положительной оценкой и всего 3 единицы с отрицательной оценкой. Примеры слов с положительной оценкой: близкий (24 примера) и ближайиий (2); лучиий (18) и хороиий (6); старый (10), давний (8) и старинный (2); большой (8); настоящий (5); искренний (2); закадычный (2); добрый (1); любимый (1), надежный (1). Мы затруднились с определением типа оценки (и есть ли она?), имеющейся у слова заклятый в словосочетании заклятый друг, поэтому не брали в расчет эти примеры (их в нашей выборке 2).

Примеры слов с отрицательной оценкой: одномернылй (1), бывиий (1), не очень умный (1).

Приведенные данные - 89 положительный контекстов для слова друг и всего 3 негативных - свидетельствуют, по-нашему, о том, что концепт ДРУГ по-прежнему занимает прочное место среди положительных ценностных ориентиров субъектов современного русского медиадискурса.

\section{Друг - с положительной коннотацией}

Как уже было сказано выше, в 24 микроконтекстах (из 150) друг наделяется признаком «близкий», и это наиболее часто встречающееся в сочетании с существительным друг прилагательное. Еще в 2 микроконтекстах 
используется форма ближайший. Например: у меня там много близких друзей / песня «Подруга» написана о реальной жизни моих ближайших друзей. Ближайиий - это, по всей видимости, не превосходная степень от близкий, а элатив, то есть ближайший друг - это 'очень близкий друг'. В микроконтекстах со словосочетаниями близкий друг и ближайиий друг говорится о действительно дружеских отношениях: друг при этом именуется еще и соратником, родным, многолетним партнером, упоминаются разговоры на кухне (место, где русские ведут задушевные разговоры), горечь от потери близкого друга, когда он умер. Лишь в одном примере словосочетание близкие друзья заключено в кавычки - в нем, во-первых, цитируется другой источник информации, во-вторых, этими близкими друзьями (друзьями Владимира Путина) названы ключевые должностные лица в энергетическом и банковском секторе. Т.е. закавычивание словосочетания близкие друзья можно интерпретировать и как иронию, ведь обезличенные должностные лица вряд ли могут являться чьими-то друзьями.

В 24 микроконтекстах друг характеризуется прилагательными лучиий (18 примеров) и хороший (6). Например: лучиим другом считал бабуику / IIумахер - мой хороший друг. Примечательно, что в 6 случаях словосочетание лучший друг используется в политическом контексте, например: Кадаффи был лучиим другом Парижа, Лондона, Ваиингтона / лучиим другом американских жениин (о Билле Клинтоне) / Белоруссия позищионирует себя как лучшего друга России. В одном примере используется известное метафорическое наименование собаки: лучиий друг человека.

Как показала Е.В. Урысон, для того, чтобы назвать человека другом, «обычно требуется достаточно длительное время» (Урысон 2004. 297). Наша выборка свидетельствует о том, что указание на длительность отношений чрезвычайно важно для субъектов современного русского медиадискурса: прилагательные старый (10 примеров), давний (8) и старинный (2) 
встречаются в сочетании со словом друг 20 раз. Словосочетание старый друг чаще использовано при наименовании конкретного человека с указанием его имени, например: своего старого друга Даниэля Карвальо / старому другу Гриие / старого друга Генку-Слесаря. В 1 примере говорится о фильме «Старый друг», а использование определенных слов, словосочетаний в названиях художественных произведений, как известно, говорит о нерядовой роли этих слов, словосочетаний для культуры. В 1 примере словосочетание старые друзья использовано не по отношению к человеку, так названы исторические союзники страны.

Словосочетание давний друг в 7 случаях из 8 использовано по отношению к конкретному человеку, называются имена и / или фамилии таких друзей и, подчеркнем, речь идет о друге в единственном числе. Словосочетание давние друзья, т.е. друзья - по множественном числе, использовано в описании конфронтации, пример: между давними друзьями произошел конфликт.

В 8 микроконтекстах в нашей выборке встретилось определение больиой по отношению к другу. В 3 случаях речь идет о констатации факта: людей связывает дружба. В 3 случаях контекст использования словосочетания больиой друг характеризуется положительной эмоциональной окраской, например: большие друзьл, которые подзаряжают меня своей энергией /мне с ним очень хороио работалось, мы были больиими друзьями. В 2 случаях словосочетание больиой друг используется для наименования политических субъектов или субъектов политики, например: не самый больиой друг России известный бизнесмен Дональд Трамп / намного больиими друзьями России на Украине являются люди постарие или не получивщие прививки бандеровскими идеяли хлопиь и девчата Новороссии. Отметим, что в примере про Дональда Трампа говорится не о большом друге, а о не самом большом друге. В примере про Украину вновь звучит чрезвычайно актуальная в 2014 г. для России тема украинско-российских отношений, и интерпретируется она антиукраински (мы 
делаем такой вывод на основании использования субъектом дискурса выражения прививка бандеровскими идеями).

В 5 примерах используется характеристика настояиий, например: Ронни был моим настояцим другом много лет / есть не просто издатели, а настоящие друзья, единомышленники / остались в прекрасных человеческих отночениях, стали настоящими друзьями. В нашу выборку также попало по 1-2 примера таких положительньх определений друга, как искренний (2); закадычный (2); добрый (1); любимый (1), надежный (1). Контексты употребления перечисляемых в этом абзаце прилагательных в сочетании со словом друг характеризуются положительной эмоциональной окраской; и в одних случаях речь идет о частной жизни человека, в иных - о политической жизни страны (например, Уго Чавес, большой и искренний друг России). Лишь в одном случае речь идет не о положительных вещах, напротив - о прерывании дружеских отношений, пример: вчерашние закадычные друзьл не здороваются при встрече из-за возникиих идеологических разногласий. Это цитата из текста «Украина движется к развалу». Как видим, вновь звучит украинская тема (что не удивительно, ведь выборку составили тексты 2014 г., а именно в этом году разразился украинско-российский конфликт), причем субъект дискурса, скорее, не нейтрален, а излагает пророссийскую мейнстримную точку зрения относительно украинского кризиса.

\section{Отрицательная характеристика друга}

В 3 микроконтекстах в нашей выборке существительное друг сочетается с прилагательными одномерный (1 пример), не очень умный (1), бывиий (1), имеющими отрицательную коннотацию. В первых двух случаях (одномерный и не очень умный) речь идет о характеристике личных качеств человека, в третьем примере - бывиий друг - также присутствует отрицательная оценка, но, возможно, не друга, а всей ситуации - это может быть сожаление о том, 
что не тот человек являлся другом или горечь оттого, что дружеские отношения перестали иметь место.

Еще в 3 микроконтекстах негативная оценка появляется благодаря контекстам употребления анализируемых нами словосочетаний: главный друг (1 пример) и влиятельные друзья (2 примера). Словосочетание главный друг употреблено по отношения к США, и это выражение звучит иронично (в контексте речь идет о «гегемонах мира», проамериканских настроениях). Влиятельные друзья - это словосочетание также является не констатацией факта, а эвфемизмом, подразумевающим прагматичных фигурантов большой политики или олигархии, например: не без помощи влиятельных друзей стал региональныл депутатом. Примечательно, что признаком «влиятельный» (в форме множественного числа - влиятельные) субъект дискурса наделяет не своих друзей, а друзей кого-то иного, о ком говорит в 3-ем лице

В 2 примерах употреблено словосочетание заклятые друзья, например: нашим заклятым друзьям не нужна картинка «Путин разгневался и ввел на Украину войска». В словарях русского языка дается два значения лексемы «заклятый»: 1) такой, на которое наложено заклятие, 2) вечный, непримиримый. В качестве примеров приводятся сочетания со словами «враг», «противник». В наших же примерах наблюдается оксиморон: сочетание несочетающихся смыслов, порождающих художественный эффект. Судя по контексту, речь все же идет не о конкурирующих друзьях, а о действительных противниках.

\section{О географической принадлежности друга}

В 26 микроконтекстах существительное друг сочетается с прилагательными, указывающими на географическое положение друга в мире, или его национальную принадлежность, или его родной язык и проч. Например: у меня есть русский друг / мои иностранные друзьл по fb / позвонил своим севастопольским друзьям/вывел на сцену чернокожего друга. 
Самая многочисленная группа сходных по смыслу примеров - это 5 микроконтекстов, в которых речь идет об украинских или киевских друзьях. Актуальность украинской темы обусловлена, несомненно, событиями в Киеве 2014 г. (выборку составили тексты 2014 г.). В 1 из наших примеров субъект дискурса говорит об украинских друзьях (прекрасных друзьях) и украинской революции в положительном ключе: больиинство моих прекрасных украинских друзей поддерживало Майдан. Примечательно, что в этом примере друзья именуются прекрасными. В 2 же случаях микроконтексты явно свидетельствуют об украинско-российском противостоянии, имевшем место в 2014 г.: один из редких киевских друзей, с кем после майдана остались прежние отночения / другой мой (бывиий) киевский друг не посчитал возможным далее обиаться с «клятым москалем» и вывесил черно-красный бандеровский флаг вместо картинки пользователя в сочиальной сети. В данных примерах нельзя не отметить, что «после майдана» у субъекта дискурса осталось мало друзей в Киеве, а также слова редкий и бывиий, а также нанизывание слов с отрицательной коннотацией (с точки зрения представителя русской культуры) - клятый, москаль, бандеровский, таким образом, контекст говорения о друзьях (пускай редких и бывших) получается весьма экспрессивным, и подспудно говорящий проводит мысль о том, что на фоне украинско-российского конфликта украинские товарищи ведут себя неадекватно.

Также многочисленную группу примеров составляют такие микроконтексты, в которых речь идет об американских (или проамериканских) «друзьях»: американские, заокеанские, западные, зарубежные. Слово друзья мы заключили в кавычки, так как во всех этих примерах оно употребляется иронически, речь идет не о дружеских отношениях, напротив. Несколько примеров: создание постоянного очага напряженности на границе с Россией - это сейчас главная задача организаторов этих событий: наиих американских друзей / наии последние разработки могут быть бессовестным 
образом заимствованы наиими любимыми заокеанскими друзьями / наии американские друзья, они изощренные ребята. Как видим из этих примеров, американские друзья стремятся к созданию напряжения на границах России, могут бессовестно заимствовать идеи, а в непроцитированных нами примерах речь идет о третьей мировой, освещению военного украинского конфликта $в$ выгодном ключе, силой своего авторитета реиительно опровергать всякие контрреволючионные домысльи и проч.

Еще 2 примера (речь в которых идет уже не об американских, а о китайских и арабских друзья) также свидетельствуют о том, что те, кого в современном русском медиадискурсе именуют друзьями, не обязательно обладают традиционно приписываемыми другу в русской языковой картине мира положительными качествами. Положительные качества друга для русских - это готовность помочь, выслушать, понять. В наших же примерах говорится: наии китайские друзьл - сложные, тяжелые переговориики / мы должны дать ясно понять наиим арабским друзьям ... что мы никогда не будем поддерживать ... режимы ... убивающие христиан. В обоих случаях слово друзья явно использовано не в своем прямом значении, речь не идет о дружеских отношениях. Скорее, «друзьями» именуется сторона, с которой приходится иметь дела в силу обстоятельств.

В ряде примеров, в которых используется словосочетание «прилагательное ‘географическая принадлежность' + друзья), повествуется о партнерстве без подвоха, например: рассматривали вопросы к визиту вьетнамских друзей / позвонил своим севастопольским друзьям / азербайджанские друзья построили в Астрахани мост Дружбы.

В нашей выборке был также обнаружен пример, иллюстрирующий положение о том, что социальная сеть «Фейсбую» способствует расширению понятия «друзья»: мои иностранные друзья по fb вылазят туда не чаще раза в месяц. Как известно, люди, с кем пользователь «Фейсбука» устанавливает 
контакт, входят в список, именуемый «Друзья». Система не предлагает ранжирования контактов пользователя по степени или типу близости (например, коллеги, родственники, одноклассники, знакомые, общие знакомые и проч.). Таким образом, получается, что у пользователя «Фейсбука» столько «друзей», сколько контактов. Тогда как до эпохи социальных сетей считалось, что у русских могут назвать другом небольшое количество людей (для большинства личных связей использовались слова приятель, товарищ, знакомыцй). По всей видимости, русскоговорящий осознает, что друзья в реальной жизни и друзья по социальным сетям - это разные категории личных связей, и именно поэтому, употребляя слово друзья по отношению к контактам из «Фейсбука», он добавляет уточнение друзья по $f b$, как в приведенном нами выше примере.

В тех случаях, когда субъекты дискурса используют слово друг в единственном числе, речь идет о действительно дружеских отношениях: подарил немечкому другу (машину) / у пацанов есть русский друг Юра / их азербайджанский друг по фамилии Манафльл.

\section{Характеристика совместной деятельности}

Искушенный читатель сразу же отметит, что в русской языковой картине мира для наименования партнеров, объединенных общим делом, обычно используют слово товарищ (это отмечается в работах посвященных анализу семантики синонимов друг, товарищ, приятель и др.). Наши данные не противоречат этому положению, в нашей выборке встречается всего 4 прилагательных, которыми субъект дискурса характеризует друга по обозначению общей для друзей сферы деятельности: это деловые друзья (2 примера), то есть друзья по бизнесу, студенческие (1), то есть объединенные совместными штудиями, спортивные (1) - друзья по спорту, звездныле друзья (1) - коллеги в музыкальной области деятельности. 


\section{Констатация факта}

В ряде случаев друг наделяется не оценочной характеристикой и не данными о его культурной или профессиональной ориентации, попросту субъекты дискурса констатируют факт, что друг, о котором идет речь в тексте, является другом реальным (а не воображаемым) (1 пример), умериим (1) или, наоборот, здоровым (1) (в сопоставлении с человеком, имеющим инвалидность), а также маленьким (1). В последнем случае речь идет, конечно же, не о степени близости друзей, а о возрасте младшего из них. В 3 примерах констатируется факт наличия общих друзей, например: спорят о том, у кого в понедельник вечером гостил их общий друг. В 1 примере также констатируется факт - посессивный признак друзей, например: Анины друзья обсуждали ее 6 coucemax.

\section{Метафоры, клише, обращения}

4 примера в нашей выборке - это устоявшиеся в русском языке метафорические наименования велосипеда - двухколесный друг (1 пример), собаки - четвероногий друг (1), растительность (парк, газон и проч.) - зеленый друг (1) и проверенный временем политический союзник - исторический друг (1). Все эти выражения еще в советское время стали газетными клише. Примеры (они довольно предсказуемые) приводить тут не будем, отметим лишь то, что историческим другом названа Украина. Опять проявляется украинская тема, неизбежное следствие того, что анализированные нами тексты оыли опубликованы в 2014 году.

В нашу выборку попало также 4 примера употребления словосочетания дорогой друг или дорогие друзья в качестве обращения. Примеры столь немногочисленны, по-видимому, потому, что при обращении к действительно дорогому другу русский предпочтет использование имени человека, а не его статуса в отношениях адресат-адресант. 


\section{Личный друг}

В нашу выборку попал 1 пример употребления словосочетания личный друг. Пример: Бородай, бывиий пиариик и личный друг «главнокомандуюшего силами ДНР» и министра обороны ДНР Игоря Стрелкова. Что в данном примере дает говорящему использование прилагательного личный? Иными словами, чем отличаются друг и личный друг? По-видимому, говорящий хотел подчеркнуть исключительность отношений двух людей, о которых он пишет, но сказать «близкий» или «старый», или «хороший» друг субъект дискурса не счел возможным. Примечательно, что личные друзья имеются только у сильных мира сего (по данным Google - российский олигарх, личный друг президента Путина; личный друг Вайизеккера; личный друг Фиделя) или у детей (при этом речь, как правило, идет о собаке). Интересно также и то, что ни в одном из трех массовых ассоциативных опросов, о которых говорится выше, слово личный ни разу не выступило реакцией на стимул «друг».

\section{Новые друзья}

«Старый друг лучше новых двух», - говорят русские. Ценность проверенных временем дружеских отношений для русских очевидна (это показывают и количественные данные нашей выборки - 20 употреблений прилагательных с семантикой старины в сочетании с существительным друг). Но и новые друзья у русских тоже случаются, как говорится в процитированной пословице, и в нашей выборке обнаружено 3 примера словосочетаний новые друзья. Важным представляется то, что тут используется именно форма множественного числа. Друг - это более интимное слово, нежели - друзья.

В 2 контекстах употребления словосочетания новые друзья говорится не о личных дружеских связях. Во-первых, речь идет о людях, которые помогли собрать средства на лечение ребенка, пример: У нас поябилось огромное количество новых друзей. Нетипичность такого высказывания для русской 
речи подтверждается использованием обозначения количества друзей огромное количестьо. Как показано во многих работах, посвященных исследованию понятия ДРУГ, для русской картины мира большое количество друзей не характерно. Во-вторых, еще один пример, в котором сказано о новых друзьях, - это: мы только радь будем новым друзьял и новым профессионалам в наших рядах. Тут говорится о сотрудничестве с крымскими организациями.

Третий пример использования словоформы новые как характеристики слова друзья: ее непутевал мамама Тамара Романович после развода перебралась в Кииинев $к$ новым друзьям-иыганал. В данном примере мы видим три лексемы, «компрометирующие» слово друзья: это непутевая, развод и цыгане. Слово непутевал обладает отрицательной оценкой, слово развод само по себе не является оценочным, но оно относится к денотату с отрицательной составляющей, и, наконец, слово цыгане - несмотря на популярность ценности политкорректности, все же до сих пор и это слово, и представители нации, называемой этим словом, вызывают настороженность у русскоязычного получателя информации.

\section{Заклютение}

Подытоживая сказанное выше, отметим еще раз, что сравнение количества примеров, в которых словоформы лексемы «друг» сочетаются со словами с оценочной окраской, дало такой результат: 89 словосочетаний с положительной оценкой и всего 3 словосочетания с отрицательной оценкой. Словосочетание верный друг ни разу не было использовано субъектами медиадискурса (в то время как в трех массовых ассоциативных экспериментах, давших материал для базы данных русского ассоциативного словаря, слово верный являлось наиболее частотным среди прилагательных-реакций на стимул «друг»). Слово друзья употребляется в противоположном смысле (“не 
друзья'), если оно сопровождается прилагательными американские, заокеанские, зарубежные. Словом друзья могут именоваться сложные, не обязательно дружески настроенные, партнеры. Во множестве текстов, попавших в нашу выборку, звучит украинская тема (речь идет об отношениях с украинскими друзьями, взаимоотношениях игроков политической арены и проч.), что обусловлено, по всей видимости, тем, что нашу выборку составили тексты 2014 г. - это время, когда вспыхнул украинско-российский конфликт. В текстах, в которых затрагивается тема украинского кризиса, субъекты дискурса излагают пророссийскую мейнстримную точку зрения относительно украинского кризиса. Личные друзья имеются только у сильных мира сего. В тех случаях, когда субъекты дискурса используют слово друг в единственном числе и характеризуют друга по его географической принадлежности, речь идет о действительно дружеских личных отношениях («друзьями» во множественном числе часто именуется сторона, с которой приходится иметь дела в силу обстоятельств). Прилагательные старый, давний и старинный встречаются в сочетании со словом друг 20 раз. Прилагательное новый - 3 раза, и во всех этих случаях речь идет или об обезличенных друзьях, или о подозрительных друзьях.

\section{Литература}

1- Арапова О.А. (2005). Концепт «Дружба»: системный и функциональнокогнитивный анализ: дис. канд. филол. наук, Москва, Изд-во «РГБ».

2- Вежбицкая А. (2001). Словарный состав как ключ $\kappa$ этносоциологии $и$ психологии культуры: модели «дружбыл» в разньт культурах // Понимание культур через посредство ключевьх слов. Пер. с англ. А.Д. Шмелева, Москва, Изд-во «Языки славянской культурь». - С. 63-210.

3- Демографический ежегодник России (2017). Режим доступа: http://www.gks.ru/free_doc/doc_2017/demo17.pdf

4- Коняева Е.В. (2014). Концепт «Дружба» по данным научных исследований. Режим доступа: http://elar.urfu.ru/bitstream/10995/28010/1/sk_2014-08.pdf 
5- Лунцова О.М. (2008). Градиент-концепт дружба - мир - вражда в русской и английской лингвокультурах (на материале лексики и фразеологии): дис. канд. филол. наук, Волгоград, Изд-Во «ВГПУ».

6- Национальный корпус русского языка. Режим доступа: www.ruscorpora.ru

7- Пахомова В.М. (2015). Сопоставительный анализ концепта друг/friend в английском и русском язылках // Молодой ученьий. - № 15.2. - С. 59-62.

8- Попович Е.С. (2016). Социальньге аспекты развития концепта «друг» в русском языке // Научный журнал КубГАУ. - № 115 (01). Режим доступа: http://ej.kubagro.ru/2016/01/pdf/79.pdf

9- Шмелев А.Д. (2002). Отношения между людьми // А. Д. Шмелев. Русская языковая модель мира: материальг к словарю, Москва, Изд-во «Языки славянской культуры». - С. 164-188.

10- Шутковски Т. (2010). «Дружба» $и$ «друг» в языковой картине мира: на материале паремиологических трансформ // Studia Rossica Posnaniensia. - № 35 - C. 281-287.

11- Черкасова Г.А. (2008). Русский сопоставительный ассоциативный словарь, Москва, Изд-во «ИЯз РАН». Режим доступа: http://itclaim.ru/Projects/ASIS/RSPAS/SPAS_3.htm\#tri20

12- Чугаева Е.С. (2016). Концепт «дружба» в русской паремиологической картине мира // Научное и образовательное пространство: перспективы развития: материаль ІІІ Междунар. науч.-практ. конф. (Чебоксары, 13 нояб. 2016 г.). В 2 т. Т. 2 / Редкол.: О.Н. Широков [и др.], Чебоксары, Изд-во «ЦНС Интерактив Плюс». - С. 67-72.

13- Урысон Е.В. (2004). Друг 1. Приятель 1. Товарищ. // Новый объяснительный словарь синонимов русского языка. Под ред. Ю.Д. Апресяна. Второе издание, исправленное и дополненное, Москва; Вена, Изд-во «Языки славянской культуры: Венский славистический альманах». - С. 297-299. Режим доступа: http://www.lrc-lib.ru/ruslang/noss/text.pdf

14- Хизова М.А. (2005). Концепт «дружба» в русской и английской лингвокультурах: автореф. дис. канд. филол. наук, Краснодар, Изд-во «Институт экономики, права и естественных специальностей».

\section{Bibliography}

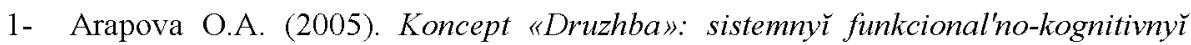
analiz: dis. kand. filol. nauk, Moskva, Izd-vo «RGB».

2- Vezhbickaja A. (2001). Slovarnyj sostav kak kljuch k jetnosociologii i psihologii kul'tury: modeli "druzhby» v raznyh kul'turah /" Ponimanie kul'tur cherez posredstvo kljuchevyh slov. Per. s angl. A.D. Shmeleva, Moskva, Izd-vo «Jazyki slavjanskoj kul'tury». - S. 63-210.

3- Demograficheskij ezhegodnik Rossii (2017). Rezhim dostupa: http://www.gks.ru/free_doc/doc_2017/demo17.pdf 
4- Konjaeva E.V. (2014). Koncept «Druzhba» po dannym nauchnyh issledovaniŭ. Rezhim dostupa: http://elar.urfu.ru/bitstream/10995/28010/1/sk_2014-08.pdf

5- Luncova O.M. (2008). Gradient-koncept druzhba - mir - vrazhda v russkŏ $i$ angliǔskoĭ lingvokul'turah (na materiale leksiki i frazeologii): dis. kand. filol. nauk, Volgograd, Izd-vo «VGPU».

6- Nacional'nyj korpus russkogo jazyka. Rezhim dostupa: www.ruscorpora.ru

7- Pahomova V.M. (2015). Sopostavitel'nyj analiz koncepta drug/friend v anglijskom $i$ russkom jazykah // Molodoj uchenyj. - № 15.2. - S. 59-62.

8- Popovich E.S. (2016). Social'nye aspekty razvitija koncepta «drug» v russkom jazyke // Nauchnyj zhurnal KubGAU. - № 115 (01). Rezhim dostupa: http://ej.kubagro.ru/2016/01/pdf/79.pdf

9- Shmelev A.D. (2002). Otnoshenija mezhdu ljud'mi // A. D. Shmelev. Russkaja jazykovaja model' mira: materialy $k$ slovarju, Moskva, Izd-vo «Jazyki slavjanskoj kul'tury». - S. 164-188.

10- Shutkovski T. (2010). «Druzhba» $i$ «drug»v jazykovoj kartine mira: na materiale paremiologicheskih transform // Studia Rossica Posnaniensia. - № 35 - C. 281 287.

11- Cherkasova G.A. (2008). Russkij sopostavitel'nyj associativnyj slovar', Moskva, Izd-vo «IJaz RAN». Rezhim dostupa: http://it-claim.ru/Projects/ASIS/ RSPAS/SPAS_3.htm\#tri20

12- Chugaeva E.S. (2016). Koncept «druzhba»v russkoj paremiologicheskoj kartine mira // Nauchnoe i obrazovatel'noe prostranstvo: perspektivy razvitija: materialy III Mezhdunar. nauch.-prakt. konf. (Cheboksary, 13 nojab. 2016 g.). V 2 t. T. 2 I Redkol.: O.N. Shirokov [i dr.], Cheboksary, Izd-vo «CNS Interaktiv pljus». - S. 6772 .

13- Uryson E.V. (2004). Drug 1. Prijatel' 1. Tovarishh. // Novyj ob\#jasnitel'nyj slovar' sinonimov russkogo jazyka. Pod red. Ju.D. Apresjana. Vtoroe izdanie, ispravlennoe i dopolnennoe, Moskva; Vena, Izd-vo «Jazyki slavjanskoj kul'tury: Venskij slavisticheskij al'manah». - S. 297-299. Rezhim dostupa: http://www.lrelib.ru/ruslang/noss/text.pdf

14- Hizova M.A. (2005). Koncept «druzhba»v russkoj i anglijskoj lingvokul'turah: avtoref. dis. kand. filol. nauk, Krasnodar, Izd-vo «Institut jekonomiki, prava i estestvennyh special'nostej».

\section{HOW TO CITE THIS ARTICLE}

Makarova, V. (2019). Tell Me, Who Is Your Friend: Concept of FRIEND in the Modern Russian Media Discourse (on the Material of the Russian National Corpus 2014). Issledovatel'skiy Zhurnal Russkogo Yazyka I Literatury, 13, 135-153.

DOI: 10.29252 /iarll.13.135

URL: http://journaliarll.ir/index.php/iarll/article/view/49

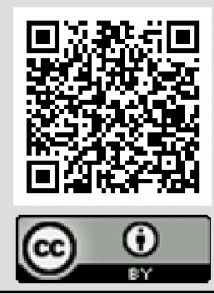




\title{
به من بخو دوستت كيست: مفهوم (دوست) در زبان رسانهاى روسيه معاصر (بر
}

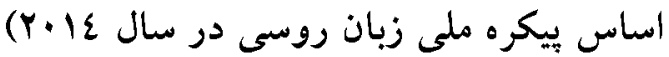

\author{
ويكتوريا ولاديميروونا ماكارووا'

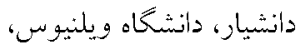

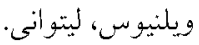

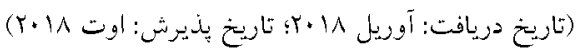

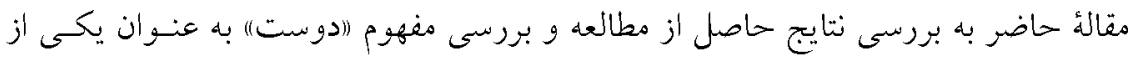

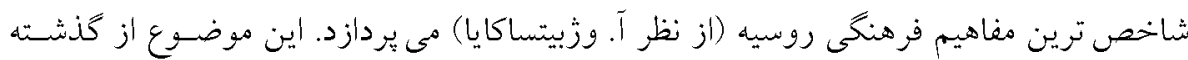

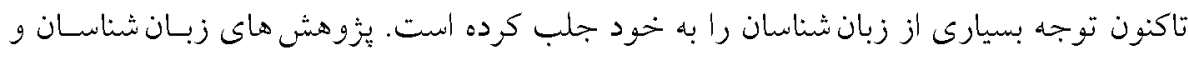

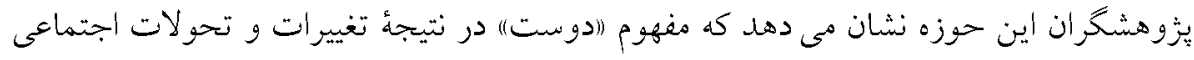

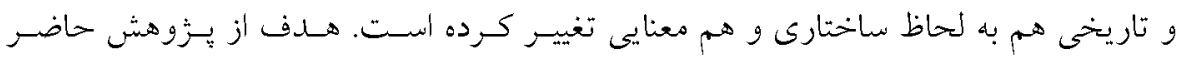

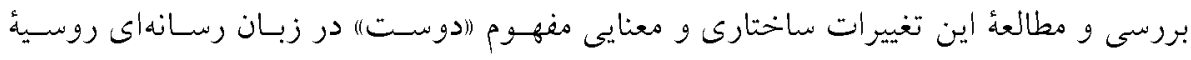

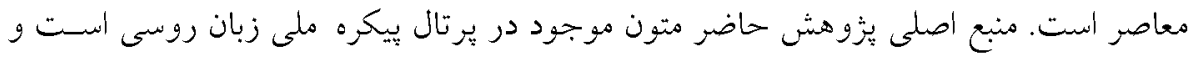

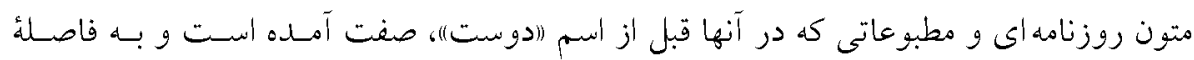

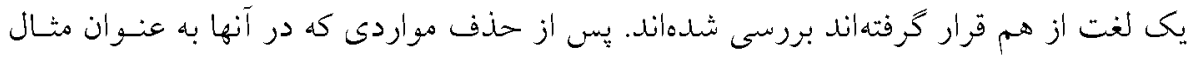

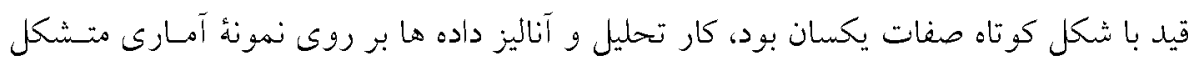

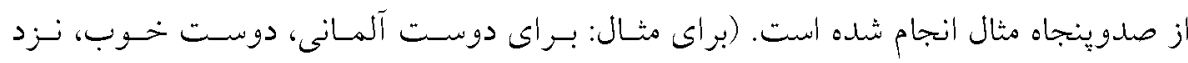
دوستان جديد، بهترين دوست).

وازٔكان كليدى: مفهوم، تصوير از جهان، دوست، دوستى، زبـان رسـانهاي، ييكـره ملـى زبـان 